\title{
A Voz do Trabalhador - jornal operário
}

MOACYR FLORES*

Resumo: Este artigo tem por propósito reconstituir artigos publicados no jornal $A \mathrm{Voz}$ Operária, de orientação comunista, e que registra o fim da Federação Operária do Rio Grande do Sul (FORGS).

Abstract: This study aims to reconstruct articles of the newspaper A Voz Operária, of communist orientation, from the last years of the Federação Operária do Rio Grande do Sul (FORGS).

Palavras-chave: Jornal operário. Comunismo. Federação Operária.

Keys words: Labor newspaper. Communism. Trade Union.

A partir de 14 de outubro de 1933, circulou em Porto Alegre o jornal $A$ Voz do Trabalhador, órgão oficial da Federação Operária do Rio Grande do Sul (FORGS), que era publicado aos sábados. O último exemplar é de 17 de setembro de 1934. Os originais encontram-se no Museu do Trabalho, em Amsterdã. Graças ao empenho do Dr. Nicanor Letti, que fez doação do microfilme ao Círculo de Pesquisas Literárias do Rio Grande do Sul, foi possível consultar esse jornal. A coleção é incompleta.

A redação localizava-se na sede da FORGS, na rua Riachuelo, $\mathrm{n}^{\circ} 1038$, com expediente em dias úteis das 20 às 22 horas e nos domingos das 9 às 12 horas. O redator responsável era o barbeiro e militante comunista Policarpo Hibernon Machado, secretário geral Theodoro Johansson e tesoureiro Carlos Gloger. Faziam parte da comissão fiscal: Moacyr Vernieri, Romanguera Basseda e Edgar Guilloux.

A FORGS surgira em setembro de 1906, organizada pelo grupo socialista dirigido por Francisco Xavier da Costa, desenvolvendo uma política sindical orientada pela social-democracia alemã. Em 1910, os anarquistas conseguiram eleger a diretoria e to-

* Professor do Programa de Pós-Graduação em História da Pontifícia Universidade Católica do Rio Grande do Sul. 
mar conta da orientação da FORGS, que se filiou à Associação Internacional dos Trabalhadores em Berlim. Na década de 1920, o movimento sindical brasileiro entrou em decadência, fracionado pelas diferentes correntes políticas (Marçal, 1985, p. 19-21).

O governo provisório de Getúlio Dornelles Vargas expediu o Decreto $\mathrm{n}^{0}$ 19.770, de 1931, determinando a organização de sindicatos de trabalhadores. Cada sindicato de classe, constituído num município, precisava do reconhecimento pelo Ministério do Trabalho. A FORGS reorganizou-se em fevereiro de 1933, lançando um manifesto em 30 de julho de 1933, com o objetivo de reunir os trabalhadores em sindicatos e com programa de ações, publicado no jornal A Voz do Trabalhador, $\mathrm{n}^{-1}$, de 14 de novembro de 1933: intelectualização do proletário através de palestras sobre higiene, leis e decretos; combate sistemático ao alcoolismo e ao jogo; rudimentos de Medicina preventiva; criação do Liceu de Artes e Ofícios; organização de escolas nos bairros operários; luta pela jornada de trabalho oito horas e campanha em prol da sindicalização.

No jornal n 3, de 28 de outubro de 1933, há críticas a Ernani de Oliveira, inspetor regional do Ministério do Trabalho, que recebeu 108 processos movidos por sindicatos de trabalhadores contra seus patrões. Em todos os processos, os patrões tiveram ganho de causa. Em números seguintes, o redator ataca o desempenho de Ernani de Oliveira. Na primeira página do $n^{0} 4$, o jornal denuncia o inspetor Ernani de Oliveira por sempre dar ganho de causa aos patrões e de realizar contratos coletivos que burlavam as leis trabalhistas. O telegrama enviado pela FORGS, com assinatura de representantes de 24 sindicatos, ao ministro do Trabalho, Joaquim Pedro Salgado Filho, é transcrito na íntegra, exigindo a demissão do inspetor regional. A Voz do Trabalhador $\mathrm{n}^{\circ} 5$, de 11 de novembro de 1933, anuncia na primeira página a visita do Ministro do Trabalho à cidade de Porto Alegre para verificar as denúncias de que o secretário da FORGS estaria mancomunado com elementos indesejáveis para promover a anarquia. Na realidade, a FORGS teria solicitado um inquérito para apurar irregularidade na execução das leis trabalhistas, acobertada pelo inspetor regional Ernani de Oliveira. Esses ataques ao inspetor regional provocaram a saída de vários sindicatos da FORGS, que apoiavam as reformas trabalhista do governo.

Em vários números, o jornal publica denúncias sobre a exploração dos trabalhadores por parte dos patrões. Na Mina de Butiá, os mineiros eram obrigados a comprar carne a $1 \$ 300$ réis o quilo. Os 300 réis a mais eram destinados a saldar a dívida de $200 \$ 000$ réis que a administração contraiu com o açougueiro. Outra exploração era a forma de pagamento da produção dos minei- 
ros e dos "tocadores" de carro: em todas as minas pagavam por tonelada extraída, enquanto que na Mina de Butiá, primeiro o minério passava por cinco peneiras, extraindo a "moinha", só depois o carvão era pesado. A companhia mineradora vendia a tonelada da "moinha" por $25 \$ 000$, sem pagar aos mineiros. O Hotel Schmitt despedia o trabalhador que se sindicalizasse. O restaurante Treviso e o Hotel Majestic não concediam repouso semanal a seus empregados. A situação do proletariado no interior era mais difícil. Em São João de Montenegro, São Leopoldo, Novo Hamburgo, Cachoeira do Sul e outras localidades os patrões estavam dispensando ou rebaixando os salários dos trabalhadores sindicalizados. Os operários de Novo Hamburgo ainda reivindicavam jornada de oito horas, estabelecida por lei. Triunfo já contava com um sindicato oficializado. A lei $\mathrm{n}^{\mathrm{O}} 22.033$ regulou a jornada de trabalho em oito horas e o descanso semanal. As empresas comerciais de Porto Alegre, principalmente hotéis, bares, cafés e restaurantes, negavam-se a cumprir a lei e passaram a contratar diaristas. O jornal publica na íntegra o Decreto $\mathrm{n}^{\circ} 22.979$, sobre a duração e condições de trabalho dos profissionais empregados em barbearia e congêneres ( $A$ Voz do Trabalhador, $\mathrm{n}^{0} 3$ ). Sob o título de necessidades vitais, o jornal divulga a situação miserável da habitação, instrução e alimentação do operário, que ganha apenas para comer e não para se alimentar. Noutro artigo comenta a situação dos operários da Companhia Minas do Recreio, em São Jerônimo, condenados à miséria por causa dos salários atrasados em mais de um ano e que na cooperativa dos proprietários só havia bolachas, bacalhau e tamancos. Denunciada ao Ministério do Trabalho, a Companhia pagou os salários atrasados e despediu os mineiros (A Voz do Trabalhador, $\mathrm{n}^{\circ} 3$ ). Denuncia o bar Antonello, que burlava a proibição de mulheres trabalharem após as 10 horas da noite, firmando um contrato com 10 garçonetes de alocação de mesas ( $A$ Voz do Trabalhador, $\mathrm{n}^{\circ} 4$ ). Há, na página dois, denúncias sobre estabelecimentos que não cumprem a lei das oito horas de trabalho. No Hotel do Comércio, as cozinheiras e copeiras trabalham ininterruptamente, sem direito e nem tempo necessário para refeições, das 5 horas às 22 horas. No Hotel Majestic continuava a jornada de 9 horas e meia de trabalho. O Bar Florida desconhecia a lei das 8 horas. Nos restaurantes e cafés do Mercado Público, os patrões determinavam a jornada, que era superior a estabelecida pela lei ( $A$ Voz do Trabalhador, $n^{0} 5$ ).

A FORGS comunica que Gustavo Jahn, dono de fábrica de cerveja em Montenegro, obrigou seus operários, sob pena de serem demitidos, assinarem uma convenção de trabalho com jornada de 9 
horas e com redução de salário. Na última página, retornam os ataques ao inspetor regional Ernani de Oliveira, com a publicação do acordo realizado com os mineiros do Butiá e a diretora da Companhia Carbonífera Rio-grandense, em que os trabalhadores são prejudicados nos descontos dos vales, no preço da carne e no pagamento ( $A$ Voz do Trabalhador, $\mathrm{n}^{-} 6$ ). Uma caravana composta por oito operários percorreu as olarias situadas na margem do rio Caí, em São João de Montenegro, a fim de sindicalizar os operários. Foi bem recebida por patrões e operários, somente a Firma Lerch continuava demitindo ou rebaixando em $50 \%$ os salários dos operários ( $A$ Voz do Trabalhador, $\left.\mathrm{n}^{0} 4\right)$.

O jornal $n^{9} 7$, continua com denúncias sobre estabelecimentos que não cumpre a lei sobre jornada de trabalho, como o Café Natal e o Hotel Lagache. Na terceira página, do mesmo exemplar, trata da jornada de menores nas fábricas, onde são constantes os abusos com crianças trabalhando além do horário, fazendo limpeza nas máquinas com engrenagem em movimento, provocando acidentes. A seguir, passa a comentar o decreto $\mathrm{n}^{\circ}$ 17.043, de 12 de outubro de 1927, que normatiza o trabalho de menores, proibindo que executem tarefas perigosas. Acusa a Padaria Pátria de empregar menores no turno da noite. É interessante notar que na mesma página do jornal há o aviso do Sindicato dos Operários em Fábricas de Tecidos, convocando seus sindicalizados para uma reunião a fim de discutirem o estabelecimento de uma escola noturna para filhos de operários sindicalizados ( $A$ Voz do Trabalhador, $\mathrm{n}^{\circ} 7$ ).

A Voz do Trabalhador denuncia a Padaria Jaguarense, de propriedade de Emilio Dipp, que paga seus operários com vale, papelucho sem valor, que não é aceito em nenhum lugar. O proprietário resgata o vale quando entende, alegando falta de dinheiro. Na Fábrica Renner, onde o mandatário é chefe do Partido Integralista do Rio Grande do Sul, a operária de nome Vitória afastou-se para operação de apendicite e quando retornou ao trabalho foi informada de que não havia mais vaga. Na fábrica Neugebauer, além do pagamento miserável, não há compensação proporcional ao trabalho que excede as horas normais. Afirma que "a cor dos operários é argumento para distinção odiosa" ( $A$ Voz do Trabalhador, $n^{\circ} 43$ ).

$\mathrm{O}$ jornal relata a situação dos operários na metalúrgica Abramo Ebele, onde os operários recebem 200 réis por hora e trabalham 9 horas por dia. Os operários mais antigos recebem um mil réis a hora, o que não permite satisfazer suas necessidades básicas. Na fábrica de Amadeu Rossi a situação ainda é pior, os operários são proibidos de fumar e todo aquele que passar mais de três minutos na latrina, é multado ( $A$ Voz do Trabalhador, $\mathrm{n}^{\circ} 46$ ). 
A Voz do Trabalhador acusa o Hotel Jung de explorar seus empregados, fazendo-os trabalharem de 11 a 12 horas por dia, obrigando os garçons a lustrar o chão, trabalho incompatível com suas funções. Para enganar os empregados, o relógio é atrasado durante o expediente, mas sempre está certo na hora da entrada ( $A$ Voz do Trabalhador, $\mathrm{n}^{2} 50$ ).

Na zona colonial italiana, os patrões se recusavam a aplicar a legislação trabalhista e proibiam a sindicalização. Na firma Chaves \& Almeida, de Caxias do Sul, os tecelões eram obrigados a trabalhar 10 horas por dia, em troca de mísero salário. Na tecelagem Santa Catarina, de Mateu Gianeti \& Cia., uma comissão de operário exigiu a jornada de 8 horas, recebendo como resposta do chefe da firma "que quem quisesse trabalhar que trabalhasse 10 horas por dia, porque 8 ele não dava, recomendando-lhes que não se sindicalizassem e se quisessem que se sindicalizassem em uma sociedade formada por ele e pelos padres, onde deviam pagar dez mil réis de entrada e três mil réis por mês" ( $A$ Voz do Trabalhador, $\mathrm{n}^{2} 51$ ).

A FORGS planejou uma série de cursos com especialistas que, em linguagem acessível, ministrariam disciplinas básicas e fariam conferências. O doutor Carlos Hofmeister realizou conferência sobre a higiene alimentar das crianças, dirigida a operários e suas familias, no domingo, em 22 de outubro de 1933. Na mesma página, há um artigo sobre a grande procura de livros de sociologia, economia e história, considerando um perigo, porque pessoas sem conhecimento básico das disciplinas não assimilam ou interpretam mal os livros (A Voz do Trabalhador, $\mathrm{n}^{-} 3$ ). Na noite de 26 de novembro de 1933, o Dr. Florêncio Ygartúa realizou palestra sobre "O alcoolismo e a infância", na sede da FORGS, acompanhada de projeção cinematográfica sobre o assunto ( $A$ Voz do Trabalhador, $\mathrm{n}^{\circ} 7$ ).

As greves nacionais e locais mereceram vários artigos. Em 29 de outubro de 1933, os proprietários de padarias deixaram a população sem pão porque se negavam cumprir o Decreto $\mathrm{n}^{\circ} 23.104$, de 23 de agosto de 1933, que estabelecia a jornada de trabalho e o descanso remunerado. O Sindicato dos Industriais Panificadores continuava desobedecendo o Decreto $\mathrm{n}^{\circ} 23.104$, sobre jornada de trabalho dos padeiros e promovendo campanha contra os mesmos. Das padarias existentes, mais ou menos 30, apenas nove distribuíram pão a partir das 5 horas. Nas demais, os padeiros continuavam em greve.

Apesar das novas leis trabalhistas, Getúlio Vargas enfrentava a greve dos marítimos no Rio de Janeiro e as críticas do jornal A Voz do Trabalhador, que considerava o presidente da República como um instrumento nas mãos dos imperialistas ianques ( $A \mathrm{Voz}$ do Trabalhador, $\mathrm{n}^{-} 42$ ). 
A diretoria do Sindicato dos Industriais Panificadores denunciou que estavam sendo ameaçados pelos padeiros grevistas. Os padeiros estavam em reunião na sede da FORGS, quando chegou um emissário da Polícia e convidou o padeiro Laudelino Seipa, presidente do Sindicato dos Operários em Panificação, a comparecer à Chefatura de Polícia. Laudelino suspendeu os trabalhos e foi levado em carro da polícia até a sede policial, onde estava o delegado, a diretoria do Sindicato dos Industriais Panificadores e Ernani de Oliveira, que queriam a garantia de iniciar o trabalho com repartidores, das 18 às 20 horas e não pretendiam conceder o descanso dominical completo. O Sindicato dos Padeiros declarou que elementos estranhos à classe estavam provocando desordens, prejudicando os trabalhadores honestos e sindicalizados que esperam um acordo com os patrões ( $A$ Voz do Trabalhador, $\mathrm{n}^{\circ}$ 6).

A Prefeitura de Porto Alegre aumentou as taxas sobre as chamadas "avenidas", um amontoado de casas num terreno, onde viviam trabalhadores. Os proprietários passaram as taxas para os inquilinos, aumentando os aluguéis. As vilas operárias eram formadas por agrupamento de chalés de madeira, sem higiene e sem meios de transporte. O periódico sugere o lançamento de construções de casas para operários em terrenos do Estado ou do município, através de um empréstimo a juro reduzido, cujas apólices seriam tomadas em grande parte pelos estabelecimentos industriais. O empréstimo seria destinado a construir habitações, obedecendo a uma planta oficial, com as condições de higiene, água luz e transporte a preços reduzidos e para a indispensável criação de escolas. As casas teriam isenção de impostos por tempo determinado e a Prefeitura faria uma tabela de preços de aluguel.

O jornal $n^{\circ} 6$, de 18 de novembro de 1933, anuncia os preparativos para a realização de um Congresso Operário em Porto Alegre, organizado pela FORGS. Em reunião com representantes de 26 sindicatos, a Federação deliberou realizar o Congresso Operário em fevereiro de 1934; romper com o inspetor regional Ernani Fornari e de preparar a recepção ao Ministro do Trabalho ( $A$ Voz do Trabalhador, $\mathrm{n}^{\circ}$ 6).

Dentro do movimento sindical, o Sindicato dos Operários em Fábricas de Tecidos programou, para o dia 21 de novembro de 1933, um festival em benefício de seus cofres no Cine-Teatro Talia, situado na avenida Eduardo. No dia 14 do mesmo mês, o Sindicato dos Trabalhadores em Cargas e Descargas Gerais Terrestres programou um pic-nic, em benefício do Sindicato, no Capão do Diniz, situado no Beco do Silveira, $\mathrm{n}^{\circ}$ 687, no Menino Deus. Os ingressos estavam à venda no portão da chácara ( $A$ Voz do Trabalhador, $\mathrm{n}^{\circ} 6$ ). 
A Voz do Trabalhador $n^{0} 7$, de 25 de novembro de 1933, abre a primeira página com a transcrição de um jornal do Rio de Janeiro, intitulada "Aspectos do Fascismo Brasileiro", definido como um movimento retrógrado que defende os privilégios da burguesia, expandido sua propaganda em países com grande massa de operários como Alemanha, Itália e Inglaterra, bem como em países retardatários como Portugal e Brasil. O fascismo italiano vestiu a camisa preta do anticlericalismo, do socialismo e do capitalismo, inspirado na legenda do império romano. Mussolini adaptou-se à circunstância política italiana, buscando apoio no clero e na burguesia até assumir o poder. Na Alemanha, Hitler adotou uma ação política baseada na férrea disciplina militar dos alemães, organizando suas "tropas de assalto" que combateram os sindicatos marxistas e socialistas, esmagando o proletariado, mantendo os privilégios dos capitalistas e da burguesia. $\mathrm{O}$ artigo critica os fascistas brasileiros que vestem uma camisa oliva (azeitona) e pretendem formar um Estado Integral, onde não haverá lutas de classes e nem de partidos, porque todos obedecerão à batuta do Grande Chefe Plínio Salgado ( $A$ Voz do Trabalhador, n 7).

No artigo "Dever Supremo", é tratada a crise que afeta toda a humanidade, com a destruição de milhares de toneladas de gêneros de primeira necessidade por causa da superprodução, enquanto o proletariado vive na miséria. Com a falta de capital, que em fuga se concentra em mãos de poucos, pequenos industriais e pequenos proprietários chegam à ruína e deixam sem trabalho centenas de trabalhadores. Conclama os trabalhadores para se unirem aos sindicatos, a fim de lutarem pelo integral cumprimento das leis, pois a maioria dos operários ainda não recebe salário correspondente ao seu trabalho ( $A$ Voz do Trabalhador, $\mathrm{n}^{\circ} 7$ ).

Infelizmente a seqüência dos números do jornal é interrompida, faltam os exemplares de número 8 a 22 . O jornal n. 23, de 17 de março de 1934, só tem três páginas microfilmadas, faltando a quarta página. Desde outubro de 1933, o barbeiro comunista Policarpo Hibernon Machado esteve como secretário-geral da FORGS, tornando-se presidente da federação em maio de 1934, provocando o afastamento de vários sindicatos, que apóiam a política trabalhista de Getúlio Vargas.

Sob o título "Liberdade", o redator narra que os dirigentes da FORGS foram a Caxias do Sul e que quando se preparavam para retornar a Porto Alegre, foram abordados por dois inspetores de polícia, que os levaram para uma sala, procedendo rigorosa revista da cabeça aos pés, pois os identificavam como perigosos extremistas a serviço de Moscou. Na página dois, escreve sobre a re- 
cepção aos camaradas presidente e secretário-geral da FORGS em Caxias do Sul. No sábado realizou-se uma assembléia geral na União Sindicalista de Caxias, quando discursaram o presidente da União e o secretário-geral da FORGS, que falou sobre os fins do sindicalismo e os direitos dos operários.

Nova falha na coleção: faltam os números de 24 a 39. Do número 40, de 21 de julho de 1934, foram microfilmadas três páginas. Numa coluna inteira, o redator estabelece as reivindicações mais urgentes do proletariado: a) aumento geral e imediato dos salários, salário mínimo de acordo com o custo de vida, abolição das multas, pagamento em dia dos salários; b) comitês de empresa eleitos pelos trabalhadores, sem intervenção do Ministro do Trabalho, para controlar a admissão e demissão de operários, das condições de salário e da higiene; c) jornada de 8 horas, sem redução de salário; d) repouso semanal, férias anuais de 13 dias, com salário integral e garantia de emprego; e) fornecimento gratuito de roupas de trabalho.

Além desses itens, o redator reivindicava liberdade imediata e anistia ampla para todas as pessoas deportadas nacionais e estrangeiras por questões sociais, por luta por pão, terra e liberdade; direito de existência aberta para o Partido Comunista, Federação da Juventude Comunista, Confederação Geral do Trabalho no Brasil e suas federações, Socorro Vermelho, organizações sindicais revolucionárias e demais organizações de massas laboriosas; dissolução e desarmamento das polícias especiais, dos corpos e bandos fascistas, integralistas, patrionovistas, legionários e etc.; reconhecimento imediato e incondicional da União Soviética; contra a introdução do serviço militar obrigatório, pela retirada das tropas brasileiras do Chaco, contra os orçamentos e créditos militares; contra a remessa de gêneros e materiais de guerra para o Japão, Paraguai e Bolívia; pela expulsão das missões militares e navais estrangeiras. No final, reivindica liberdade para as nacionalidades oprimidas: negros e índios e outras nacionalidade, com direito a igualdade econômica, política e social; devolução de terras roubadas aos índios pelos imperialistas e pelo Serviço oficial de Proteção aos Índios, pelas ordens religiosa e grandes proprietários de terra; direitos de ter suas escolas e bibliotecas com suas línguas e costumes próprios (A Voz do Trabalhador, $n^{4} 40$ ).

Sob o título de "Anauê", comenta que o escritor José Jobim publicou o livro O Despertar da Alemanha, onde consta que Plínio Salgado viajou à Europa com tudo pago por Benito Mussolini. O autor do livro encontrou Plínio Salgado em Paris e o levou ao Café Glace, servido por "mulheres nuas que pegam o dinheiro de uma 
maneira toda especial". Plínio Salgado tornou-se cliente do café e recebeu o apelido de Le Tout Laid (O Feíssimo). No final do artigo, pergunta o que pensariam Lili, Mimi, Jeanette e Manon se soubessem que Plínio Salgado era defensor da santa moral católica no Brasil ( $A$ Voz do Trabalhador, $\mathrm{n}^{\circ} 40$ ).

Na $A$ Voz do Trabalhador $n^{\circ} 41$, de 28 de julho de 1934, há um artigo na primeira página sobre a Liga Eleitoral Proletária, classificando a política no Brasil como estando numa "fase feudo colonial, com todas as características de uma escravatura herdade dos próprios africanos, sob o azorrague do imperialismo do dinheiro". Os políticos da burguesia brasileira fazem torneios de lingüística com programas enganatórios, abusando da fé popular tripudiando desdenhosamente sobre a sinceridade das turbas gementes. Apresenta como solução a implantação de uma política proletária, uma política que responsabilize os representantes dos trabalhadores através da Liga Eleitoral Proletária ( $A$ Voz do Trabalhador, $n^{\circ} 41$ ).

Os congressistas da Assembléia Constituinte aprovaram a nova Constituição e elegeram Getúlio Dornelles Vargas para presidente da República. A Voz do Trabalhador critica o pleito presidencial, que foi assistido com mal contida repulsa pelo proletariado, pois não faz diferença quem ocupa o poder, pois a injustiça com os trabalhadores continuará. Ironiza a frase de Getúlio: "o mal que aflige o Brasil não é político e sim econômico". O articulista cita que Marx já disse isso setenta anos atrás.

O articulista não se deu conta de que Getúlio Vargas estava se tornando popular entre os proletários em decorrência de seus decretos e leis que regulamentaram o sistema de trabalho no Brasil.

A FORGS comunica que na assembléia de 3 de julho de 1934 expulsou do seu seio a diretoria do Sindicato dos Operários e Empregados em Tramways como indignos e traidores da classe. $\mathrm{O}$ tramway era o popular bonde, que em português era denominado de carril, daí o surgimento da Companhia de Carris Urbano ou simplesmente Carris, atual empresa de ônibus da Prefeitura de Porto Alegre. Em coluna ao lado da comunicação, reproduz o anúncio sobre a venda do folheto "A questão operária e a derrocada capitalista", pelo preço de $1 \$ 000$ réis. Segundo o anúncio, quem comprasse o folheto estaria se instruindo e cooperando com a causa trabalhista. Na secretaria da FORGS, estava à venda o livro Anais do Congresso Operário de $1^{\circ}$ de maio de 1934. Durante o Congresso Operário, o Sindicato dos Operários em Panificação apresentou a tese: "nenhuma organização operária poderá até o próximo congresso se dirigir à Inspetoria do Trabalho e nem mesmo reclamar direitos de seus associados". A proposta extremista foi aprovada. 
A Liga Eleitoral Proletária (LEP), fundada em Porto Alegre a 16 de julho de 1934, com o objetivo principal, conforme artigo IV de seus estatutos, de "colocar representantes em todos os departamentos da legislação burguesa, para fazer da mesma uma tribuna de propaganda de suas idéias, bem como lançar mão de 50\% dos subsídios, a fim de empregá-los na difusão das reivindicações trabalhistas por meio de jornais, folhetos e conferências proletárias". Foram eleitos como secretário geral Policarpo H. Machado e secretários Ângelo Plastina, Carlos Gloger, Leopoldo Machado e Agnaldo Teixeira, como tesoureiro geral Moacyr Varniere e tesoureiro auxiliar Geraldo Teixeira. Havia a Comissão de Propaganda, a de Finanças e a Caravana de Propaganda, esta para viajar pelo interior.

Um longo artigo refere-se à luta da China contra o imperialismo, dividida em dois governos, um feudal-burguês, do sanguinário Chang Kai Chek, e outro dos sovietes dos operários, localizado ao sul da China, onde estava a vanguarda da revolução mundial.

A Voz do Trabalhador $\mathrm{n}^{\circ} 42$, de 4 de agosto de 1934, traz na primeira página uma resenha sobre a excursão da caravana da LEP a Rio Grande e Pelotas. Na sede de União Operária de Rio Grande realizou-se a assembléia de massa para formação do Comitê da LEP. Em Pelotas, a Caravana teve dificuldades em arregimentar os operários por causa da sabotagem dos dirigentes da Frente Sindicalista de Pelotas, que não distribuíram os boletins que convocavam para a assembléia da LEP. O Sindicato dos Motorneiros (os que dirigiam bonde) recebeu a caravana em sua sede. No dia seguinte, os chapeleiros procuraram os membros da caravana, para expor sua miséria, pois estavam trabalhando de dois a três dias por semana. Mesmo sem propaganda, a caravana reuniu uma assembléia de massa no cinema Apolo, domingo pela manhã, quando foi aprovada a proposta da formação de um comitê da LEP.

A partir de agosto de 1934, a nova diretoria da FORGS era composta por Policarpo H. Machado (barbeiro), vice-presidente Geraldo Teixeira (estivador), secretário geral Moaré Martins (gráfico), secretário Millan Knafelz (metalúrgico), tesoureiro geral Francisco Gonçalves (garçom), tesoureiro José P. Dussarat (marceneiro) e procurador Leopoldo Machado (padeiro). A comissão de Finanças era formada por Raimundo Martins (mosaista), José dos Santos (tintureiro) e Quintiliano Lima (motorneiro).

Walter Pompeu assina o artigo "Staline - o homem de aço", no qual aborda as transformações ocorridas no mundo após a guerra de 1914-18, com o aumento de despesas dos Estados, o 
surgimento da realidade do desequilíbrio social e o crescimento da inflação gerando a crise econômica. Considera a democracia como um regime moribundo e Hitler um ingênuo que tenta manter o povo faminto dentro de uma disciplina férrea, enquanto a Rússia é o único país que se libertou do capitalismo, formando uma nação organizada, sem fome e sem miséria, pois Stalin é o estadista mais completo da época, um homem superior e audaz. Em outro artigo, há um esclarecimento de que a Frente Única Operária e Camponesa não tem nada de comum com a Frente Única feudal-burguesa pertencente aos fazendeiros e comerciantes, oriunda da fusão dos partidos Republicano e Libertador.

O famoso publicista Apparício Torelly, que se dizia o Homem Livre, publica o artigo "A democracia é uma comédia! A história é uma grande mentira!", numa linguagem irônica e cheia de chavões contra os exploradores, os espoliadores e os burgueses. Anuncia que há uma revolução em marcha dos pobres, dos espoliados e dos miseráveis. Afirma que uma revolução necessariamente não precisa derramar sangue, como a revolução industrial. Considera que o movimento de 1930 foi apenas uma divergência entre os membros da mesma classe dominante, semelhante aos demais movimentos da América Latina. Caracteriza a democracia no Brasil como uma comédia, porque é apenas um pequeno grupo que toma violentamente o poder. A imprensa, o clero, o Exército e a polícia favorecem a classe dominante e opressora, porque não passam de meros instrumentos dos capitalistas. $\mathrm{O}$ artigo continua em vários números.

Ivo Silva escreve o artigo "O salário diminuto e a mulher proletária", na primeira página da $A$ Voz do Trabalhador $\mathrm{n}^{\circ} 43$, de 11 de agosto de 1934, condenando o baixo salário que a burguesia paga aos trabalhadores, o que leva a mulher que trabalha à prostituição para satisfazer as mais prementes necessidades. Fala da desgraça da trabalhadora que se entrega ao patrão para melhorar de vida e depois é abandonada. Como a justiça humana está do lado do capital, só aos trabalhadores cabe a salvação da sociedade corrompida.

"Contra o fascismo e as guerras imperialista" não traz o nome do autor, mas concita os trabalhadores a lutar contra o fascismo e contra as guerras imperialistas.

Um grupo de intelectuais, estudantes e operários organizaram o Comitê Anti-Guerreiro de Porto Alegre, tendo como presidente o engenheiro Gabriel Pedro Moacyr, como secretária a operária Eldemira Flores Cabral, e como $1^{\text {a }}$ tesoureira a operária Laura Lange. Na assembléia de criação da nova entidade, aconteceram discursos de todas as ideologias contra a guerra imperialista. 
Continua o artigo de Apparício Torelly, criticando a revolução de 1930 e afirmando que dentro do regime em vigor, os pobres serão sempre mistificados. Jacinto Costa escreve "Brasileiros, despertamos!", onde caracteriza os brasileiros como comodistas e profundamente supersticiosos. Outro defeito apontado é a falta de organização do povo, que vive na mais completa anarquia. Os brasileiros devem despertar, porque o mundo já partiu para a grande civilização. Conclui que está na hora de o povo se organizar e livrar o Brasil da tutela dos estadistas. Em longo artigo, o redator de $A$ Voz do Trabalhador condena a caravana sindicalista, formada por representantes dos Sindicatos dos Bancários e dos Comerciários, que se desligaram da FORGS, como inimigos do proletariado.

Dando destaque dentro de uma caixa de texto, há uma ironia em forma de pseudo Concurso Infantil que promete prêmios a quem descobrir qual é o sindicato, filiado à FORGS, que está descontente com a diretoria. O prêmio seria um inspetor em conserva, uma caravana à caçadora, 19 sindicatos com petit-pois e seis potes com maionese. O pseudo-concurso mostra que a FORGS já não representa mais os proletários do Estado, por causa de sua orientação comunista. Os sindicatos petit-pois, isto é ervilha de cor verde, eram de orientação integralista e os da maionese os que apoiavam o governo.

"Teatro do Povo ou teatro popular?" é o título em primeira página do jornal $\mathrm{n}^{\circ} 44$, de 18 de agosto de 1934 , com crítica ao artigo publicado no Correio do Povo sobre o teatro do povo, conceituado como sendo a totalidade dos indivíduos para a conquista da verdade e da beleza. A Voz do Trabalhador considera povo como a palavra mágica da burguesia reacionária, ocultando que o proletário só se redime através da luta de classe para implantar a ditadura do proletariado. Afirma que é necessário um teatro para educação da consciência de classe, "teatro para o desmascaramento da burguesia, que focalize a fome, a prostituição, o terrorismo policial, a brutalidade fascista e todas as podridões do regime burguês".

Na página dois, do no 43 , "Esclarecendo os fatos" disserta sobre a confusão reinante com tantas leis e decretos, que provoca inquietação nos proletários. Apresenta como causas das calamidades sociais do Rio Grande do Sul, além da opressão do capital e da subversão moral do clero, a ação do inspetor regional do trabalho, que conduz os proletários ao holocausto, pois é conivente com os patrões que não cumprem as leis trabalhistas. 
O jornal publica o longo manifesto do Comitê Central de Greve dos obreiros da cidade de Santos, na sua luta contra a fome, a reação, a guerra e o fascismo.

Há um ataque com versos de poeta anônimo aos padres. A crítica se justifica porque a Igreja despertou e resolveu evangelizar os operários através dos Círculos Operários, na tentativa de anular a propaganda comunista.

No artigo "A hora atual", consta que as reformas demagógicas do governo estão de acordo com os partidos burgueses. Restam apenas os comitês operários para lutar pela defesa do postulado: a igual trabalho, igual salário para ambos os sexos, liberdade em todos locais de trabalho, contra a opressão fascista, contra as guerras imperialistas, contra o desemprego e pelo ensino laico.

O comitê Anti-Guerreiro de Porto Alegre convida os proletários e os intelectuais para uma grande assembléia, na Avenida Eduardo, dia 19 de agosto, onde seriam discutidos assuntos referentes ao programa do comitê e difundidos os princípios doutrinários.

A Voz do Trabalhador publica mais um trecho do artigo de Torelly, em que explica que o socialismo de Estado é um regime de transição, conforme mostra a sociologia, enquanto a história universal é uma mentira, porque é escrita por escribas e cronistas alugados à classe dominante.

A Voz do Trabalhador, $\mathrm{n}^{\circ} 45$, de 25 de agosto de 1934, apresenta o artigo "Recomeçou a comédia", ironizando o retorno dos exilados políticos, que recomeçaram os discursos políticos, os comícios e as correrias nas ruas. Vivem entre discursos e banquetes, ensaiando outra comédia semelhante à de 1932. No final, o chefe da mazorca assumirá o comando.

$\mathrm{Na}$ assembléia do dia 13 de agosto da Liga Eleitoral Proletária (LEP) foi aprovado o documento de reivindicação para os trabalhadores do campo: direito de plantar em seu benefício em terras não cultivadas; direito de pescar, caçar e tirar lenha e carvão, monopolizados pelos fazendeiros; mercado livre de impostos para seus produtos; pagamento em dinheiro de todos os dias de trabalho; direito de transitar livremente pelas estradas, sem pagar impostos; médicos e remédios por conta dos fazendeiros e governo; anulação de todos os impostos que pesam sobre o pequeno agricultor; baixa em $50 \%$ nos fretes para o pequeno agricultor; pela anulação dos sindicatos capitalistas da erva, da banha, fumo, madeiras, arroz e etc.; criação de Ligas Camponesas para controle da produção e garantia das reivindicações; fornecimento gratuito pelo governo de utensílios como bois, arados, tratores, arame e de 
terras; direitos do peão de morar em casa, ao invés do galpão; estabelecimento de 8 horas de trabalho diário; retirada dos capatazes; retirada dos sinos de chamada; descanso dominical.

A fim de divulgar as proposta, a LEP organizou uma caravana formada pelos camaradas P. H. Machado, Leopoldo Machado, Euclides de Souza e Lucas Netto.

Na primeira página, consta um soneto de autoria de Lavrador, com o título de "Visão Vermelha", que no último verso exalta "O lábaro da foice e do martelo". A bandeira com a foice e o martelo não agradou aos sindicatos que começaram a abandonar a FORGS, apoiando as medidas trabalhista do governo.

No artigo "Dissecando um regime agonizante", o publicista analisa a crise do capitalismo oriunda de suas próprias contradições, explorando as classes trabalhadoras. Erra ao afirmar que o espírito revolucionário germina na consciência das massas. Conclama pela união dos explorados contra a canalha burguesa.

O jornal publica o comunicado da Sociedade Luz, agremiação dos russos brancos ucranianos, sobre a reunião realizada no dia $1^{\underline{0}}$ de agosto, quando foram debatidos os temas "Quais são os motivos das guerras imperialistas? O que pensam os operários sobre elas?". Estiveram presentes 135 pessoas. A presidente Maria Timoszuk finaliza com: "Necessitamos paz, vida, serviço e pão! Abaixo a tapeação das religiões! Viva a união dos trabalhadores do mundo!".

O Sindicato dos Trabalhadores em Calçados e Classes Anexas de Porto Alegre anuncia um grandioso festival em benefício da Caixa Beneficente, no dia 13 de setembro de 1934, no Teatro Baltimore. Por se tratar de uma festividade meramente proletária, o secretário Paladio Bastos contra com o apoio dos seus camaradas.

No artigo "Educação Classista", o autor considera que os sistemas pedagógicos são veículos de cultura em todos os regimes, que preparam para a dominação, tanto os que serão dominantes como os dominados. Com a industrialização, os instrumentos da cultura são postos para criar operários aptos com o mínimo de instrução, a fim de melhor explorar o proletariado. Nas escolas públicas a educação cívica incute idéias de pátria, autoridade e religião nos filhos dos proletários. A pátria é a da burguesia, pois a pátria dos proletários, a União Soviética, não é citada na escola. A idéia de autoridade leva ao aburguesamento dos proletários, enquanto que a religião, verdadeiro ópio do povo, prega o desprezo pelas coisas do mundo e promete uma vida com recompensas em outro mundo, facilitando a explora- 
ção. É necessário que os pais coloquem os filhos em guarda contra a intoxicação da escola burguesa. Cabe às mulheres proletárias a grande tarefa de apressar a formação da consciência de classe da infância proletária.

O "Quadro Número..." lembra a tragicomédia da vida, gerada pela miséria no regime capitalista. À moça órfã sem instrução e sem emprego só resta prostituir-se. A justiça social está na morte que nivela os pobres e os ricos.

A Voz do Trabalhador transcreve uma crônica de Rubem Braga, publicado no Diário de Notícias, em 21 de agosto de 1934. O tema é o ouro de Moscou enviado aos comunistas brasileiros, que vivem em pensão, perdendo as malas com suas roupas, porque não têm dinheiro para pagar aluguel. Outro assunto desenvolvido é o medo que as pessoas têm do comunismo e que os brasileiros preferem manter relações comerciais com o diabo do que com a Rússia.

Continua a publicação de mais um fragmento do artigo de Apparício Torelly, elogiando o espírito eslavo que está construindo o Estado socialista em Moscou.

No artigo "Destruir para construir", o articulista é contra tudo, até contra a caridade que alimenta os proletários com as sobras dos ricos. Destruir o mundo capitalista para construir um mundo socialista, de acordo com Karl Marx.

Da cidade de Santa Maria vem um longo artigo dirigindo-se aos camaradas espoliados, com várias citações de Karl Marx, destacando a lei de mais valia.

No $\mathrm{n}^{\circ} 46$, de $1^{\circ}$ de setembro de 1934 , Ivo Silva escreve o artigo intitulado "A sociedade na lei natural da evolução", usando dados incompletos sobre a evolução (na realidade mudança) da sociedade através das revoluções em busca da liberdade, como a que obrigou João Sem Terra a dar a Magna Carta, culminando com a Revolução Russa. Outro artigo na primeira página trata das guerras interimperialistas, conclamando os operários a participar do Comitê Anti-Guerreiro.

No rodapé, em letras maiores, consta que a polícia fascista de Cachoeira do Sul tentou impedir a propaganda da Liga Eleitoral Proletária, prendendo os membros da Caravana que saiu de Porto Alegre e o presidente do Sindicato dos Operários Panificadores de Cachoeira. Depois que foram soltos, realizaram um comício em praça pública. 
Na segunda página, consta o manifesto dos ferroviários da Estrada de Ferro Sorocabana, que denuncia a falta de apoio dos deputados classistas, que não representam o proletariado.

No final da página, o jornal reproduz um texto de Lenin: "Palavras de Lenin à juventude: serás em breve um homem; irão dar-te uma arma. Segura-a e aprende bem a arte militar. Esta ciência é indispensável aos proletários, não para disparar contra teus irmãos, os operários dos demais países, como se faz na guerra atual e como te aconselham os traidores do socialismo, mas para combateres a burguesia do teu próprio país, para pôr fim à exploração, à miséria e às guerras, não com votos piedosos mas com a vitória sobre a burguesia e seu desarmamento".

Há um artigo contundente contra os exploradores imperialistas da Companhia Carris, que recolheram de cada trabalhador uma caução de 250 mil réis, que não foi depositada em banco, mas usada em benefício da Companhia. Informa que os bondes trafegam lotados, o que provoca erros de contagem de passageiros por parte dos fiscais, prejudicando o condutor.

De Santa Maria um articulista anônimo escreve contra o Estado, que serve apenas para oprimir. Critica o projeto de fundação do Banco Rural, que irá apenas servir aos grandes agricultores e criadores, sem se preocupar com os pequenos.

No rodapé há um convite para operários, mulheres trabalhadoras e desempregados para comparecerem à grande assembléia de massa organizada pelo Comitê Anti-Guerreiro, na Avenida Eduardo 528, bonde São João.

A Voz do Trabalhador relembra a execução de Nicolau Sacco e Bartholomeu Vanzetti, em 23 de agosto de 1927, nos Estados Unidos. Citando essa data como uma injustiça aos trabalhadores, o Partido Comunista, a Confederação Geral do Trabalho no Brasil e o Comitê Anti-Guerreiro realizaram manifestações no Rio de Janeiro, São Paulo e Porto Alegre. No Rio de Janeiro, a assembléia operária reunida no Teatro João Caetano foi dissolvida violentamente pela polícia que, segundo o jornal, teria assassinado e ferido homens, mulheres e crianças.

"A questão judaica" é um pequeno artigo sobre a liberdade e igualdade que a minoria dos judeus goza na União Soviética, onde as massas trabalhadoras foram integradas ao trabalho de edificação de sua pátria socialista. 
A Voz do Trabalhador $\mathrm{n}^{0} 47$, de 8 de setembro de 1934, traz em manchete "O 2 Congresso Ferroviário Brasileiro", realizado em Porto Alegre, em 2 de setembro, no qual a FORGS apresentou a tese de luta de classe, contrária aos grupos chamados de traidores do proletariado.

O jornal publica as reivindicações dos marítimos: cumprimento das 8 horas de trabalho; melhoria de alimentação e higiene a bordo; equiparação dos salários com os do Lloyd Brasileiro; Instituto de Pensões e Aposentadorias pago pelos armadores ao governo; aposentadoria para todos os marítimos inválidos; retirada da polícia dos sindicatos; auxílios aos desempregados marítimos e portuários, pagos pelos armadores e governo; completar as tripulações; abolição das multas a bordo; cumprimento da lei de férias; regularização dos trabalhos.

No rodapé, o jornal arremessa uma farpa a Plínio Salgado, chefe dos integralistas: "Plínio Salgado, o salamandra, acha-se em Porto Alegre para pregar o fascismo aos trabalhadores. À sua passagem deve-se levantar o braço e descer com força". Critica o jornal integralista $A$ Ofensiva, que sugere que os cães de fila da Polícia Central tenham livre trânsito pelas estações de estrada de ferro, a fim de que possam perseguir os elementos nocivos à sociedade. A Voz do Trabalhador considera que os elementos nocivos são os trabalhadores conscientes que lutam por seus próprios interesses. Segundo o articulista, o jornal integralista era mantido pelo conde Crespi, magnata do leite Vigor, por Osvaldo Aranha, através de verba do Departamento Nacional do Café, e por Góes Monteiro.

No microfilme constam duas páginas de $A$ Voz do Trabalhador $\mathrm{n}^{\circ} 48$, de 15 de setembro de 1934 . Na primeira página, registra a reação da polícia de Santa Maria, que prendeu os componentes da caravana de LEP, remetendo-os sob escolta pelo trem, a Porto Alegre.

Em Pernambuco criaram a Ação Pernambucana contra o Fascismo, representado no Brasil pelo integralismo. Em Porto Alegre, Plínio Salgado realizou uma conferência no Cinema Navegantes. $\mathrm{O}$ articulista traça uma caricatura cáustica do líder integralista: "Plínio é um homem alto, magro, protótipo do 'girava', bigodinho mosca, sistema Hitler, seu dindinho, fala fina e afeminada, jogo de cena bastante cômico: coloca as mãos nas ancas e reboleia as formas, gesto típico dos atores sem graça".

Rubem Braga assina o artigo "Animais sem proteção", onde ironiza o decreto 24.645, que coloca todos os animais na categoria de tutelados pelo Estado e que ninguém pode mantê-lo em cativeiro em lugares sem higiene, que devem receber medicamentos e 
não podem estar encerrados com outros animais doentes. Braga compara a situação de outro animal, parecido com os seres humanos, que trabalha em fábricas sem higiene, doentes e que sofrem maltrato. Diz que esses animais são considerados por algumas pessoas como humanos, mas não são homens, são operários.

A Voz do Trabalhador $\mathrm{n}^{\circ} 49$, de 22 de setembro de 1934, publica ao pé da página "Lição de Rosa de Luxemburgo", que focaliza o tema do fim da sociedade capitalista e o dia de julgamento de seus crimes. Considera que o crime mais horrendo da tirania capitalista é contra as crianças proletárias.

Em outro artigo, o articulista critica o inspetor Ernani de Oliveira, chamando-o de mistificador tartufo por causa do discurso proferido na Sociedade Contabilista de São Leopoldo, onde referiu que parte dos trabalhadores não compreenderam a importância da sindicalização e que há uma luta contra a legislação social. Ora, estas colocações atingiram diretamente o engajamento político comunista da FORGS, que reagiu com seu artigo violento contra Ernani de Oliveira e com outro artigo intitulado "A obra nefasta dos capachos", que inicia de maneira mordaz: "A camarilha capitalista pelos seus sequazes, os doutorecos, os altos funcionários, banquistas e comerciantes, tendo à frente o malabarista puxador do burlesco cordão de batuta em punho, o celebérrimo Ernani, estão empregando todos os meios para regerem a orquestra furiosa e desarticuladora, que se esfrangalha de encontro à parede granítica do proletariado consciente". E por aí continua com sua ironia, o articulista que esconde sob o pseudônimo de Cabral.

A redação declara que não é verdade que 32 sindicatos de Pelotas deram solidariedade à caravana Godoy Ilha \& Cia., que percorre o Estado em propaganda da Inspetoria Regional do Trabalho, conforme notícia da imprensa burguesa. A Sociedade União Operária declara que, dos 13 sindicatos, apenas o dos Bancários resolveu apoiar a caravana dos "confusionistas amarelos", a serviço da burguesia para enganar os proletários. A Voz do Trabalhador conclama os operários para votarem nos candidatos da Liga Eleitoral Proletária, condenando as caravanas eleitoreiras que percorrem o interior.

Noutro artigo concita os trabalhadores para a formação de comitês de frente única nas fábricas para lutar por aumento de salário, alimentação abundante e sã, 8 horas de trabalho, descanso semanal, pagamento de horas extras com $100 \%$ de aumento, habitação confortável e higiênica, serviço médico e farmácia gratuitos, suspensão do trabalho aos menores de 14 anos, três semanas antes e três depois do parto pagas pelos patrões, trabalho igual com 
salário igual para todos, seguro social e de vida aos inválidos, escolas gratuitas, lotes de terra aos cultivadores, uso gratuito da água e direito de carregar armas de caça e de defesa pessoal.

Na página quatro, conclama novamente para a formação de comitês nas fábricas, nas empresas, nas oficinas e em todos os recantos de trabalho a fim de protestarem contra a reação policial que foi desencadeada sobre os companheiros Mário Canto, Hamilton Vieira, Salomão Chapiro, Miltom Krafeltz e Alberto Fernandes, cujo paradeiro é ignorado. O jornal informa que na firma Gruen \& Belfinger Ltda, construtora das pontes metálicas da Variante Barreto, tem a seu serviço $70 \%$ de estrangeiros e que o capataz, alemão nato, perseguiu e demitiu um caldeireiro brasileiro. $\mathrm{O}$ articulista considera esse fato como mais uma prova do internacionalismo da burguesia e da exploração dos trabalhadores. Há nota da Delegação do Sindicato Brasileiro dos Bancários do Rio de Janeiro, esclarecendo que o presidente da entidade não quis pôr em votação a moção de protesto contra a prisão de líderes operários. O jornal continua condenando as guerras imperialistas que massacram as massas trabalhadoras. Classifica o Partido Liberal e a Frente Única como partidos burgueses, restando ao operário a Liga Eleitoral Proletária (LEP).

A Voz do Trabalhador $\mathrm{n}^{0} 50$, de 29 de setembro de 1934, publica a relação dos candidatos da LEP, para deputado estadual: Policarpo H. Machado, Leopoldo Machado Soares, Agostinho Claro de Carvalho, Universina Torres Tatsch, Germiniano Cadiota Xavier, Santos Soares, Murillo Valle Machado, João Junqueira Rocha, Amâncio Cabreira, Augustin Lenusa, Alfredo Hohendorf, Abrelino Cruz, Elpídio Santos, Percy de Abreu Lima, Antônio Flegek, João Pinho e Júlio Mohr; para deputado federal Augusto Plastina, Fernando de Souza do Ó, Theodoro Joahonson, Moacyr Varnieri, Júlio de Assis Araújo, Arnaldo Teixeira, Eraclito Coco, José Lopes de Carvalho, Abílio Fernandes e Euclydes de Alencastre Fontes.

O jornal transcreve da Classe Operária, órgão do Partido Comunista do Brasil (PCB), a notícia de que Luís Carlos Prestes, que se encontra na União Soviética, ingressou na seção brasileira da Internacional Comunista.

$O$ redator critica a nota publicada por membros da diretoria do Sindicato dos Empregados da Viação Férrea, no jornal Correio do Povo, de 23 de setembro de 1934, atacando os extremistas, tendo à frente a agitadora Nina Flores, que percorrem os sindicatos com prédicas nocivas, perniciosas e condenáveis. O jornal relaciona greves no Rio de Janeiro de 19 categorias de trabalhadores, duas em São Paulo, uma na Bahia e outra nos Estados Unidos, concla- 
mando os proletários para a luta. Critica a caravana do Partido Republicano Liberal que percorre o interior do Estado, sem conseguir apoio do proletariado.

A Voz do Trabalhador $n^{0} 51$, de 6 de outubro de 1934, publica a relação dos delegados da Liga Eleitoral Proletária (LEP) do Estado. Divulga a proclamação aos trabalhadores soldados e marinheiros, estudantes e intelectuais pobres, jovens e mulheres, índios e negros, para votarem nos candidatos da LEP, contra os trotskistas, socialistas proletários, trabalhistas, economistas que traem as massas, vendendo-se aos feudais burgueses da Frente Única e do Partido Republicano Liberal. As reivindicações referem-se ao aumento de salário e diminuição de horas de trabalho; salário igual para ambos os sexos; caixa de aposentadoria; proibição para trabalho de menores de 14 anos; licença de 60 dias antes do parto e 60 dias depois; instrução primária e superior obrigatória para os trabalhadores, marinheiros e militares inferiores; igualdade de direitos para todas as raças.

$\mathrm{Na}$ terceira página, o artigo "Regime fora da humanidade" analisa a matéria publicada no Correio do Povo, afirmando que a Rússia possui um regime que está fora da humanidade. O redator do jornal comunista contesta, argumentando que desde a revolução, a Rússia vive o regime dentro dos princípios de liberdade, igualdade e humanidade, destacando cada um desses princípios a partir de premissas erradas.

Mais uma crônica ideológica prevê o fim do capitalismo e a construção de nova sociedade com os proletários revolucionários, que devem se unir com seu partido, o PCB.

A Voz do Trabalhador $\mathrm{n}^{-} 52$, de 13 de outubro de 1934 , às vésperas das eleições, abre a manchete "Desmascarando um tartufo", condenando João Miguel Vitaca, que antes fora membro da FORGS e que agora estava do outro lado político. O jornal publica em três páginas o discurso do deputado Álvaro Chaves, nas sessões de 6 e 9 de setembro de 1934, na Câmara Federal, em que defende as reivindicações dos proletários.

Infelizmente falta no microfilme o jornal $n^{\circ} 53$, edição logo após as eleições. O n² 54, de 3 de novembro de 1934, considera o 7 de novembro como uma data histórica para o proletariado mundial, porque é o $17^{\circ}$ aniversário da revolução que implantou o socialismo na Rússia, com a ditadura do proletariado e dos camponeses. $\mathrm{O}$ artigo exalta o progresso industrial russo. Outro artigo considera a URSS como a pátria internacional do proletariado, onde não existe o poder dos ricaços e o poder é exercido pelo povo. É evidente que o articulista ignorava os horrores da ditadura 
stalinista e a opressão em que o povo russo vivia. Na segunda página destaca-se o apelo ao povo trabalhador no sentido de ajudar materialmente o jornal $A$ Voz do Trabalhador, que poderá desaparecer por falta de meios. Novo apelo nesse sentido está impresso na página terceira.

Conclama os trabalhadores para a greve de massas, no dia 7 de novembro, exigindo pão, terra e liberdade, concluindo as palavras de ordem: "viva a pátria internacional dos trabalhadores! Abaixo a feudal burguesia! Abaixo o imperialismo! Viva a URSS!"

O no 55, de 10 de novembro de 1934, silencia sob o fracasso da greve geral programada para o dia 7 do mesmo mês. Por causa da orientação política comunista, tanto a FORGS como o jornal estão em seu final. Na primeira página há uma crítica contundente ao Diário de Notícias que publicou um suplemento com fotografias do Centro da cidade, querendo mostrar que Porto Alegre crescia. $\mathrm{O}$ articulista ironiza que os repórteres não fotografaram a miséria dos bairros Navegantes e São João, onde vivem os trabalhadores.

"Pela unidade sindical" é um artigo que ataca os deputados anarquistas, trotskistas, feudal-burgueses e os classistas trabalhistas e estações de rádios que servem ao governo e lutam contra os grevistas. O redator denuncia a fábrica Bier, onde os operários descontam cinco mil réis por mês para a Caixa de Socorro e só há um médico para atendimento, os doentes têm de comprar os remédios. Na seção de tinturaria pagam apenas sete mil réis para o operário, quando deveria ser mais. Na seção de fiação trabalham menores de 14 anos, o que era proibido pela legislação. No final, exige a criação de escolas e creches nos locais de trabalhos para os filhos de operários, pagas pelos patrões, liberdade para os presos políticos e dá viva aos sovietes chineses, a Cuba e a Espanha insurrecionada.

A redação avisa que o festival em benefício do jornal $A V o z$ do Trabalhador será no próximo dia 29, com a peça dramática "Deus lhe pague", de Joracy Camargo, "de fundo altamente social e doutrinário". "Deus lhe pague", criada em 1932, teve retumbante sucesso com o público. O drama aborda a hipocrisia social, vista por um mendigo, representado por Procópio Ferreira, que conversa com outro mendigo na porta da igreja. Numa das falas, o mendigo informa que "em sua biblioteca, metido num dos meus lindos robes-de-chambres, lendo Upton Sinclair, Karl Marx...". Conforme anota Magaldi, pela primeira vez o nome de Marx foi colocado em palco brasileiro, talvez daí a escolha da FORGS para encenar a peça. O jornal não informa que grupo representaria o drama, na certa não seria Procópio Ferreira. 
O nº 56, de 17 de novembro de 1934, é o ultimo exemplar que consta no microfilme. A edição é de seis páginas. A primeira página é ocupada pelo artigo "Sob o regime do esbulho e do terror" que denuncia a situação de miséria dos ferroviários e que a comissão destinada a reivindicar aumento de ordenado limita-se a enviar memorandos ao governo do Estado, esvaziando o movimento dos trabalhadores da Viação Férrea. O tema principal é sobre a ata falsa enviada ao presidente Antônio Augusto Borges de Medeiros, onde consta a demissão do camarada Pedro Berger, que fora eleito delegado-eleitor dos ferroviários.

Na segunda página, constam os resultados da assembléia geral da FORGS, com eleição da delegação que iria ao Rio de Janeiro, bem como uma coleta para custear a viagem da delegação. No centro da página publica a letra do hino A Internacional.

Na terceira página há o discurso do deputado Álvaro Ventura, do PCB, desafiando o capitão Felinto Müller a prestar declarações na Câmara Federal pelas mortes dos comunistas Tobias Warchvski, jornalista Adelino Deicola dos Santos, gráfico Mário Grazzini, alfaiate Heitor Ferreira Lima, trabalhador Severino Soares de Oliveira, gráfico Ferreira e do desaparecido Roberto Morena. Afirma que a Internacional Comunista está empenhada na lutas de massas organizadas, não no terrorismo individual e que no PCC não há lugar para assassinos e provocadores.

Noutro artigo divulga que Luís Carlos Prestes chama a atenção do Comitê Mundial de luta contra a guerra sobre os horrores do Chaco, alertando para o militarismo japonês, que necessita de base no Pacífico para suas guerras imperialistas contra a URSS.

A crônica dirigida aos ferroviários trata da organização das lutas de massas dirigidas pelo Comitê de Frente Única. Após as resoluções aprovadas em assembléia, o Comitê deve assegurar o direito do trabalhador manifestar seu pensamento; não permitir o autoritarismo e individualismo nos membros dirigentes; aplicar a autocrítica baseada na democracia proletária; não permitir que os dirigentes entendam-se diretamente com o patronato ou com a polícia, sem prévia consulta à massa; mais rigorosa vigilância de classe; denúncia imediata de qualquer elemento que esteja fazendo sabotagem, bem como dos que estejam ligados ao patronato e à polícia.

Continua o artigo de propaganda "Como vive o operário na Rússia Soviética", destacando as diversões, a liberdade, o casamento e a família, considerando qualquer informação contrária como mentirosa. Estampa o retrato do comunista Tobias Warchvsky, quando falava na praça da Harmonia, no Rio de Ja- 
neiro, na manifestação antifascista e antiguerreira de 22 de setembro, quando a polícia de Felinto Müller atirou nos manifestantes e prendeu Tobias. Seu cadáver foi encontrado numa cisterna da mata da Gávea.

Os artigos de $A$ Voz do Trabalhador permitem uma reelaboração da história das lutas dos operários por seus direitos trabalhistas. Os trabalhadores, por força do Decreto 19.770, de 1931, eram obrigados a pertencer a um sindicato que estivesse reconhecido e subordinado ao Ministério do Trabalho Indústria e Comércio. A orientação comunista de oposição ao governo de Vargas da última diretoria da FORGS fizeram com que a maioria dos sindicatos operários do Rio Grande do Sul abandonasse a Federação, que acabou se dissolvendo em 1935. Outro fator importante para esse afastamento, foi o fato de a questão social ser uma bandeira da campanha da Aliança Liberal. No entanto, não podemos deixar de registrar o papel que teve o jornal $A$ Voz do Trabalhador ao denunciar as irregularidades dos contratos de trabalho, os abusos dos patrões e em esclarecer os trabalhadores sobre os danos do alcoolismo, das drogas, do jogo e da ignorância sobre higiene, saúde e conhecimentos gerais.

\section{Referências}

MAGALDI, Sábato. Panorama do teatro brasileiro. Rio de Janeiro: Serviço Nacional de Teatro/DAC/FUNARTE, 1962, p. 187-188.

MARÇAL, João Batista. Primeiras lutas operárias no Rio Grande do Sul. Porto Alegre: Globo, 1985. 